\title{
FROM PUNJAB TO PEGGY'S COVE: \\ JOYFUL ACTIVISM IN BEHIND THE BHANGRA BOYS (2019)
}

\author{
Rohini Bannerjee \\ Saint Mary's University (Canada)
}

\begin{abstract}
This paper will examine how the 2019 Nancy Ackerman documentary film Behind the Bhangra Boys both deconstructs the complexities of contemporary Sikh immigrant identity in Eastern Canada and reinforces the intricacies of one's social responsibility of being a welcome guest on the unceded territories of Mi'kma'ki, otherwise known as Nova Scotia. Following the energetic choreography and generous hearts of five young Sikh immigrants, the film reminds viewers that the protection of community and the planet is part and parcel of joyful activism, whilst following Guru Nanak's teachings, be it along the rocky shoreline of Peggy's Cove or the fertile farmlands of Punjab.
\end{abstract}

Keywords: Behind the Bhangra Boys (2019), Sikh Diaspora in Eastern Canada, Joyful Activism.

\section{DEL PUNJAB A PEGGY'S COVE: ACTIVISMO DESDE LA FELICIDAD \\ EN DETRÁS DE LOS CHICOS DEL BHANGRA (2019)}

\section{RESUMEN}

Este artículo estudia cómo el documental Detrás de los chicos del bhangra (2019), de Nancy Akerman, deconstruye la complejidad de la actual diáspora sij en el Este de Canadá y contribuye a explicar la responsabilidad social de cada individuo para considerar la hospitalidad en los territorios Mi'kma'ki, también conocido como Nueva Escocia (Canadá). El documental describe las coreografías de este grupo de cinco migrantes sij para lanzar un mensaje de protección para la comunidad y el planeta, a través de un activismo basado en la felicidad y en las doctrinas de Gurú Nanak, la orografía de Peggy’s Cove y las tierras del Punjab.

Palabras Clave: Detrás de los chicos del bhangra (2019), diáspora sij en el Este de Canadá, activismo de la felicidad.

DOI: https://doi.org/10.25145/j.recaesin.2021.83.11 


\section{INTRODUCTION}

As Hamseet Singh Chandok declares in Behind the Bhangra Boys, "the language of dance is universal" (in Ackerman, 00:35:21-00;35:47). Nance Ackerman is an accomplished documentary filmmaker and photographer, creating images and film around the globe for over 30 years. Her social documentary films have explored topics ranging from the world of opioid drug addiction to the challenging spaces of Canada's prisons incarcerating persons who identify as women. Many of her more recent projects examine the power of the human spirit behind extraordinary global issues, including her 44 minutes documentary film, Behind the Bhangra Boys, released in 2019. Ackerman's visual appetite for storytelling comes alive as viewers capture a glimpse into the generous hearts of five young Sikh men: Hasmeet Singh Chandok, Kunwardeep Singh, Davinder Singh, Simran Singh Chadha and Bikramjit Singh. These five men moved to the unceded territory of Mi'kmaki, that is, Nova Scotia, Canada for post-secondary studies. Ackerman highlights how these vibrant spirits accomplished much more than the completion of their degree because they lived with their hearts and with their faith and decided to spread positivity through a form of Punjabi dance, bhangra, giving back wholeheartedly and in multiple ways, to the land and the people who initially welcomed them. This film, screened virtually as part of the South Asian Film Festival of Montreal in 2020, is about the power of interculturality, accepting the challenges of the immigrant/settler experience, and propelling the heart towards activism via the barrier-free and universally welcoming community that is dance.

This paper will examine how Ackerman's film Behind the Bhangra Boys both deconstructs the complexities of contemporary Sikh immigrant identity in Eastern Canada and reinforces the intricacies of one's social responsibility of being a welcome guest on the unceded territories of Mi'kma'ki, otherwise known as Nova Scotia. Following the energetic choreography and generous hearts of five young Sikh immigrants, the film reminds viewers that the protection of community and the planet is part and parcel of joyful activism, whilst following Guru Nanak's teachings, be it along the rocky shoreline of Peggy's Cove or the fertile farmlands of Punjab.

\section{THE DECONSTRUCTION}

As Chandok reminds viewers, that the point of their \#joyfulactivism videos is to "find someone who needs help and help them" (in Ackerman, 00:5:3000:5:33). The mystery of the Sikh pagh, the turban worn by some men and women following the Sikh faith, and one of the more visible identifiers of Sikhism, decreeing accountability as a servant of the Divine Presence, is instantly demystified in the very first scene of Ackerman's film. The young men are seen tying the colourful material around their long hair and head, proud smiles abounding, in preparation for a performance. The scene segues smoothly from images of sunshine shining on bright paghs to crisp icebergs crumbling into waters, as viewers prepare to learn more 
about who these young men are and how they honour not only their faith but the unceded land upon which they now work and live.

In 2016, Maritime Bhangra Group was established, perhaps unconsciously, on the principles of Guru Nanak's three main motives of living with accountability and respect: Naam Japo, the omnipresence of the Divine, Kirt Karo, a concerted effort to live in an honest and dedicated manner, and Vand Chhako, to share the fruits of one's labour with those less fortunate. And in turn, all of three Guru Nanak's teachings radiate throughout the film, in particular when Chandok mentions his father (Ackerman 00:19:27-00:19-30), a former social worker, who he lost in 2012.

In terms of Naam Japo, Ackerman provides several images of the men, gathering together, like brothers, eating together (Ackerman 00:21:45-00:22:35). The fellowship emits elements of meditation and prayer, despite not being shot inside a gurduwara but sometimes on the floor of an Ottawa hotel room as they prepare to dance at the celebrations for Canada $150^{\text {th }}$ Anniversary on Parliament Hill, in front of the Prime Minister and millions of Canadians (Ackerman 00:11:15-00:11:57), on the floor of their apartment that they share, with someone preparing masala chai and another stirring the $d h a l$. The men sit, cook, eat, in quiet, clearly conscious of the Divine ever present (Ackerman 00:5:21-00:5:30).

For Kirt Karo, viewers learn the members, whilst practicing their dances at night or on the weekends, all now have full time employment, including as an IT security consultant, a manager of a petrol station and a software developer. However, as students, they managed to stay awake for their 8:00am classes whilst working part-time, and for minimum wage, many night shifts delivering food, snow shovelling distributing flyers, working back shifts at a local Lebanese restaurant but slowly and surely, making his way up the ladder to manager (Ackerman 00:13:3500:14:05). Ackerman is realist in her approach, and she is aware that some viewers, perhaps those who do not share the lived experience of being immigrants of colour, may not know what the reality of working, studying and devoting time to activism, actually entails. The close-up shots in this scene focus on the driver and the facial expressions he makes when declaring, "sometimes it's hard to keep the negativity inside and only show positivity" (Ackerman 00;38-50-00:38-57).

As for Vand Chhako, the mere fact that when practicing their dances, either in a gym or outside, all done outside of work hours, the films are produced and posted with a clear and distinct purpose for raising funds for charity. This notion of seva ${ }^{1}$ by engaging in acts of service, on a regular basis so to become closer to the Divine, is what the Maritime Bhangra Group videos represent. Chandok asks that donations be made directly to the agency for whom the video has been prepared and that only a receipt be sent to the Maritime Bhangra Group.

\footnotetext{
${ }^{1}$ Meaning-purpose-and-importance.
} 


\section{SEVA-BLESSING OR BURDEN?}

As Elina Tujanmaa reminds us, "Gratitude is related to indebtedness, which is often defined via obligation" (64-65). In the spirit of seva, Ackerman brings to light how beyond posting dance videos for fundraising, Maritime Bhangra Group are also educators. At Dalhousie University, in Halifax, Nova Scotia, Canada, where the members were students, Chandok and others started a Sikh Student Association (Ackerman 00:15:58-00:16:15). The goal of the association was not to teach their fellow students about Sikhism, nor the practices outlined by Guru Nanak, explains Chandok (Ackerman 00:16:40-00:17:29), The purpose was to educate their peers about the choice to wear a pagh and/or keep a long beard. As Chandok reminds viewers, "sure there is joy, but there is the reality as well. It is tough being an outsider" (Ackerman 00:41:33-00:42:00). And like many persons of colour, in particular newer Canadians immigrants or migrants, there is a particular burden attached to be othered, a burden to educate, in the case of Canada, the cis-white heteronormative Catholic-Protestant majority, as Kali Holloway states:

Because here's the thing: people of color are not obligated to teach even the most well-intentioned white people anything about race. They certainly can if they want to, but it's neither their duty nor obligation. The onus rests on white "allies" to educate themselves.

Is explaining the significance of the kirpan and pagh necessary? Or does the Maritime Bhangra Group feel the unofficial burden of seva to educate the majority white population in order to feel more welcome? Ackerman offers a cozy scene between Hasmeet Chandok and Kunwardeep Singh, sitting together on the floor, where viewers hear a little more about the burden of being racialized newcomers to Mi'kmaki (Ackerman, 00:38:05-00:38:39). With comments like "you are spoiling the Maritime culture and you guys are not the Maritimes and you are not Canada" (Ackerman, 00:39:33-00:39:45). Chandok softly repeats, this xenophobia, this hatred for what is different, "it does not let us down" (Ackerman, 00:38:05-00:38:40). He refers to how improved intercultural competence starts at an early age, similar to what they are doing with their visits to schools. They are, according to Chandok, "willing to work to be called Maritimers" (Ackerman, 00:39-52-00:39-53), but of course, at what cost?

Part of the uphill battle for acceptance is due to the fact that the history of Sikh migration and settlement in Mi'kmaki is much more recent than in other areas of Canada, such as British Colombia. According to the Canadian Sikh Centre, the first Punjabi Sikhs to arrive in Canada where a small group of soldiers from Hong Kong travelling via Canada to celebrate Queen Victoria's Jubilee in 1897. More clusters of Sikh migrants made their way to the West Coast as well as to Ontario, primarily what is now known as the Greater Toronto Area. Those Sikhs who did arrive in Nova Scotia in the late 60s and early 70s, and chose to stay, worked in education and later were the founding members of the Maritime Sikh Association, which now marks 52 years of service to both the local gurudwara in Halifax. 
Thus, with little or no anchored history in the region, there is a certain ignorance of who Sikhs are, primarily amongst members of the population who are descendants of European settlers. Therefore, this alternate dimension of seva to educate children and break the cycle of ignorance is explored with Ackerman's footage of the Maritime Bhangra Group visiting a local school, where the majority of children live with developmental delays, children who themselves struggle with acceptance by greater society (Ackerman, 00:3:57-00:4:20). There are close-up shots of young children freely dancing with the Maritime Bhangra Group, huge smiles abounding, examining their paghs and beards with curiosity and humanity. Ackerman interviews the teacher in charge, whose face is visibly flushed from dancing alongside Chandok, or perhaps from the joy of seeing her students uninhibited, freeing their own minds from the burdens of being different. Chandok adds, "this is the land that accepted us as we are (in Ackerman 00:34:41-00:34:42)." Perhaps, this form of seva, showing young children it is acceptable to one's true self, is more of a blessing than a burden. Whys is this so? The author/s may want to add a sentence to specify why it is a blessing. A spiritual reward? A cultural experience? An experience of fulfillment? If so, which fulfillment?

\section{THE REINFORCEMENT}

In the second half of the documentary, Chandok humbly declares, "if you talk about change, it's all about that one drop." (Ackerman: 00:42:21-00:42:22). Ackerman brings to viewers a more in-depth view of how the Maritime Bhangra Group have made their commitment to social responsibility with the notion of \#joyfulactivism, that is, bringing joy with their dance videos as a way to be a part of the greater solution. Beyond what digital anthropologist have surmised as a phenomenon with the number of views their videos acquire, it is clear viewers are watching and donating funds to their causes. In particular, Chandok shares how the dancers prepared a video to raise money for amyotrophic lateral sclerosis or ALS research (Simran). Instead of the ice water bucket challenge that went viral across Canada, Maritime Bhangra Group decided to showcase "snow shoveler bhangra" as seen on their YouTube channel. The video received more than 50 million views in four days and consequently, thousands of dollars were raised for ALS research.

One of those viewers had her family request the dancers visit her at home and Ackerman was able to include this emotional and inter/intra cultural event into the film. Shot entirely from the kitchen and living room of this woman's home, despite being physically restricted to her wheelchair, there is clearly joy in her face (Ackerman 00:6:25-00:7:00). The camera later pans out to focus on members of the Maritime Bhangra Group huddled close to the family of the woman who has since passed from complications due to ALS. The entire group are embracing as they watch footage of the encounter, reminiscing on the joy experienced by all parties. This 'kitchen party' scene is \#joyfulactivism at its finest. These young men, without hesitation, and only with full intention to bring joy and happiness to someone whose life expectancy is limited, are described here by the family as "basically nice people 
who do good things for people and they are kind and warm. They are just that way (Ackerman 00:7:10-00:7:16). Viewers see cultural boundaries erase and simply the interaction of humans bringing other humans much joy.

\section{UNCEDED TERRITORY}

In the most powerful part of the film, the scenes that connect the Maritime Bhangra Group to their newly found roots in the Maritimes, the unceded territory of Mi'kmaki, are the shared scenes of dance intertwining both Punjabi and Mi'kmaq cultures (Ackerman 00:30:00-00:30:06) with welcoming comments from one Punjabi dancer to the Mi'kmaq dancer, "It's funny we have the exact same dance" (Ackerman 00:30:05-00:30:06). Ackerman gracefully captures the road trip of the dancers on their way from Halifax, Nova Scotia to meet Chief Matilda at Lennox Island, Mi'kmaq First Nation, Prince Edward Island. Along with a respectful choice of cinematography, one that is not touristic or voyeuristic in nature, but that gracefully captures the beautiful vistas of the land and sea of Lennox Island in ways that validate the reality of climate change, Ackerman shares with viewers a few moments of fragility and fear as well. Chief Matilda declares to Chandok and his fellow activists that the shorelines are eroding and consequently, sea levels are rising, threatening the community and indigenous ways of life.

Part of \#joyful activism for Chandok and the Maritime Bhangra Group is about highlighting a problem, like climate change and the negative effects on indigenous ways of knowing and living, but then actively becoming a part of the solution. Viewers witness the Mi'kmaq dancers preparing their headpieces for dance as well as the Punjabi dancers tightening their paghs (Ackerman 00:28:06-00:28:40). Shots of the footwork are in close range and Ackerman's gives ample room to compare how the dance steps (Ackerman 00:29:58-00:30:01) between two groups of people whose geographical origins are miles apart, are astonishingly similar. Both dances involve raising hands high up, above the air. Kunwardeep Singh explains how faslan, in Punjabi bhangra, is a dance step signifying farmers who are grateful during the time of a good harvest, giving thanks to the Earth and the Divine by swaying their hands above the head to emulate a field of crops, moving back and forth as the wind blows, personifying the land. Ackerman zooms into the reaction of the Mi'kmaq dancers during Singh's explanation and a collective understanding is acknowledged; we are all more alike than we are different.

The dance moves mirror each other, the will to honour land and water are rooted in the same intention of understanding each other and our place and duty to each other and the land. The differences between the two groups grant more opportunities to dialogue, to understand and to reflect as Chandok declares to Chief Matilda, "[w]e have come to you guys and just listen. So I think that getting that knowledge from you, I think it will give us a chance, to learn more and put in the front of the people" (Ackerman 00:29:33-00:29:35).

Chandok sees this experience to engage with the Mi'kmaq as an opportunity to act as ambassadors of change. He says, "we want to work for the issues that affect 
people and especially to the first people who us all a chance to live and work here" (Ackerman 00:34:34-00:35:35). This land, this unceded territory of Mi'kmaki, the land that has welcomed us as uninvited newcomers, this land should be honoured and preserved, according to Chandok. Viewers learn in particular from Chandok about water safety and fragility in Punjab, the province named for the five rivers merging together, (Hindi panch or Farsi panj, meaning five and $a b$, meaning water. Punjab and Mi'kmaki are both facing climate change (Ackerman 00:32:19$00: 32: 35$ ). Ackerman reminds viewers that global warming and access to safe water is a common threat around the world. This documentary's role is to highlight the intercultural activist component of reminding us that climate change and its effects are for us all to manage.

Whilst the shots of learning dance steps from each other is joyful and unifying, including observing Chief Matilda giggle in between each of her sometimes misjudged (!) bhangra steps, Ackerman allows for shots of silence too (Ackerman 00:36:34-00:36-46). Her camera is nearly perfectly still with panoramic views of Chandok and his team standing together, quietly, overlooking the flowing river, the same waters bringing life to Lennox Island and simultaneously eroding it. There are other tender moments of intercultural exchange and mutual understanding including a traditional tobacco offering (Ackerman 00:33.54-00:33:35):

Tobacco is offered for many reasons and in many different contexts. It is appropriate when asking for assistance from an Indigenous elder, knowledge keeper or person to offer tobacco. When the person accepts the tobacco, they are agreeing to help in some way. Offering tobacco is a respectful way of asking for assistance and not as symbol of gratitude after help is provided. When someone accepts tobacco, they are agreeing to listen openly and without judgement and to support you as best they can. (Carleton University)

The final scene of the Lennox Island visit is of the Maritime Bhangra Group dancing in the rain (Ackerman 00:35:06-00:35:20), perhaps nostalgic of rain scenes à la Lagaan, as outlined by Giacomo Licktner and Sekhar Bandyopadhyay, where Gujarati (Indigenous) villagers under British colonial rule pray for the rains to break the physical drought and these prayers are answered once the British leave and return the unceded land back to the first peoples. The world-wide reception of Lagaan as a landmark film of indigenous resistance to colonial occupation is important as this sense of nostalgic connection to the land is also evident Behind the Bhangra Boys. Both films respond to settlers occupying lands which later create living conditions which are unsustainable for the indigenous-first peoples of the land. Both films share cinematographic nuances of nourishing the land with heavy rains and dance scenes in the once parched land. Chandok is seen hopping into the back of the rental vehicle, in full rain-soaked garb, as they drive off, smiles abounding (Ackerman, 00:31:37-00:31-45) amongst the members of the Lennox Island First Nation, quite similar to the smiles of the Gujarati villagers as the British have their cantonment disbanded and make their way out. 


\section{CONCLUSIONS}

As Kunwardeep Singh states, "we want to interact with people and make a connection" (Ackerman, 00:10:57-00:10:59). Nance Ackerman's film is multidimensional in its approach to better understand what motivates the Maritime Bhangra Group to give so much of themselves for others. Viewers learn about how intention and passion to serve others leads to purpose. Both obstacles and blessings of life come and go for these practitioners of \#joyfulactivism and Chandok alludes to a calling, from the Divine, to serve. With the camera focusing on an image of the late Dr. Martin Luther King Jr, Chandok declares, "If they send a hateful message, we will send more love" (Ackerman, 00:40:11-00:40:12). He is asked about politics, and his answer is poignant, humble and exuding such hope, "I get into the business of change wherever it takes me, I'll go" (Ackerman 00 40:40-00:40:53).

This study has proven to viewers that the \#joyfulactivism intent and campaign of the Maritime Bhangra Group is breaking barriers. With these young immigrants wishing for positive impact, there is a better understanding of the relationship between the unceded Indigenous territory and its people, both Canadians, newly settled or with three or four generations born in Canada, and the first peoples. All of us who share Treaty land we will be alongside you, Maritime Bhangra Group, working on our cardio skills, so we can keep up! 


\section{WORKS CITED}

Ackerman, Nance, Dir. Behind the Bhangra Boys, Film, https://gem.cbc.ca/media/absolutelycanadian/episode-26/38e815a-011a94dc9d5? cmp=sch-maritime\%20bhangra\%20group.

Ackerman, Nance, blog https://reflectandrespond.com/guru-nanak-dev-ji-3-teachings-kirat-karonaam-japo-vand-chako/.

Lennox Island First Nation. https://lennoxisland.com. (Last accessed July 21 2021).

Centre for Indigenous Initiatives. Carleton University, 2021. https://carleton.ca/indigenous/policiesprocedures/tobacco-offering-protocol/. (Last accessed July 21 2021)

Canadian Sikh Study and Teaching Society. http://www.canadiansikhcentre.com/about-canadiansikh-centre/history/. Canadian Sikh Centre, 2011. (Last accessed July 21 2021).

Holloway, Kalli. "Why do White People think that People of Colour are oblitated to teach tem about Race." Alternet (8 April 2015). https://www.alternet.org/2015/04/why-do-white-peoplethink-people-color-are-obligated-teach-them-about-race/. (Last accessed, July 21, 2020).

Licktner, Giacomo \& Sekhar Bandyopadhyay. "Indian Cinema and the Presentist Use of History: Conceptions of "Nationhood" in Earth and Lagaan." Asian Survey 48/3 (May/June 2008): 431-452.

Maritime Bhangra Group. "Snow Shoveler Bhangra" (15 December 2016). https://www.youtube. com/watch?v=eHhKMu8jrfw. (Last accessed July 21, 2021).

SINGH, Simran, "Canadian Bhangra dance group surprises woman with ALS for her birthday." DH News Vancouver (15 March 2017). https://dailyhive.com/vancouver/canadian-bhangradance-group-surprise-als-birthday-march-2017. (Last accessed, July 21, 2021).

TujanmaA, Elina. "Thanks but no Thanks? Gratitude and Indebtedness Within Intergenerational Relations After Immigration." Family Relations 69/1 (2020): 63-75. 
